道路縁データからのネットワークの生成

四茂野英彦

\title{
A method to generate a road network from road margins data
}

\author{
Hidehiko YOMONO
}

\begin{abstract}
The road network analysis is one of important themes of geographic information processing and has been studied profoundly. In respect of large scaled road networks, i.e. the ones including alleys where cats roam, however, studies have just begun. It is halfly due to lack of structurized data of such large scaled networks. Recently digital geographic data have been produced and commerced for multi users. But in almost all the cases, road data are made as road margins, not as structurized networks. This study develops a method to transform such margins into networks and shows its feasibility with regard to "Numeric Map 10,000" by GEOGRAPHICAL SURVEY.
\end{abstract}

Keywords: 道路ネットワーク、数值地図 10,000、三角形分割

\section{1.はじめに}

地理情報処理の中で道路網の分析は既に長い歴史 を持つが、区画街路を対象にした分析、特に沿道の 地物や区域属性と結びつけた分析はようやく緒につ いた段階にある。区画街路のネットワーク・データ の不在あるいは作成の負荷がこの分野の理論的研究 や実際面での応用を進める上でボトルネックになっ ている。近年地図の数值化など地理情報の数値デー タとしての整備の一環として道路データの作成が各 方面で行われ、その流通も図られているが、道路縁 や付属道路施設の外形の数值化が主流であり、ネッ トワーク分析に直ちに利用できる形での供給はあま りなされていない。道路形状の視覚的提示や道路内 あるいは道路に接した施設管理がさしあったての主 要な用途であること、ネットワーク・データの作成 には道路中心線の判定や結節関係の判定など仕様を 標準化しにくい作業がともなうことなどがその原因 と考えられる。

四茂野：テ940-21 新鼬県長岡市宮関町197 長岡造形大学 Tel. 0258-21-3577

Nagaoka Institute of Design

197 Miyazeki-machi, Nagaoka-shi, Niigata 940-21
本研究は、道路形状の数値データとして一般的な 道路縁デー夕をもとに、それからネットワーク・ データを自動生成する方法を開発し、それを実際の データに適用したものである。その際、道路縁デー タが潜在的に有する幅員等の情報を点と線とからな るネットワークに結びつけることも一つのテーマと した。

従来のこうした道路ネットワーク・データの自動 生成方法としては、細線化や芯線化などの画像処理 技法を用いた例がある。しかし細街路を含む区画街 路網を処理するのにはこうした技法は必ずしも向い ていないし、特に結節の判定に難があった。この研 究ではそれに代わって三角形分割を基礎としたべク トル処理技法を開発した。次章では開発した方法を 紹介し、3章ではそれを国土地理院刊行の数值地図 10,000 に適用した結果を報告する。

\section{2. 方法}

道路縁データとしては国土地理院の数值地図 10,000 に含まれる道路データの内、平面道路のデー 夕要件を満たすものを想定した。即ち自動車専用道 
などを除く道路を平面に投影し、非道路部分の作る 面分を多角形として数值化したものである。図郭内 に包含される面分は閌じたポリライン（始点と終点 が同じ座標）となり、図郭と交差するものは開いた ポリラインとなる。な技数值地図 10,000 のデータ作 成作業基準では道路縁の方向を特定していないが、 以下の記述では方向は非道路面分を左にみるものと する。開 発した方法を 図 1 に示すテスト・データ

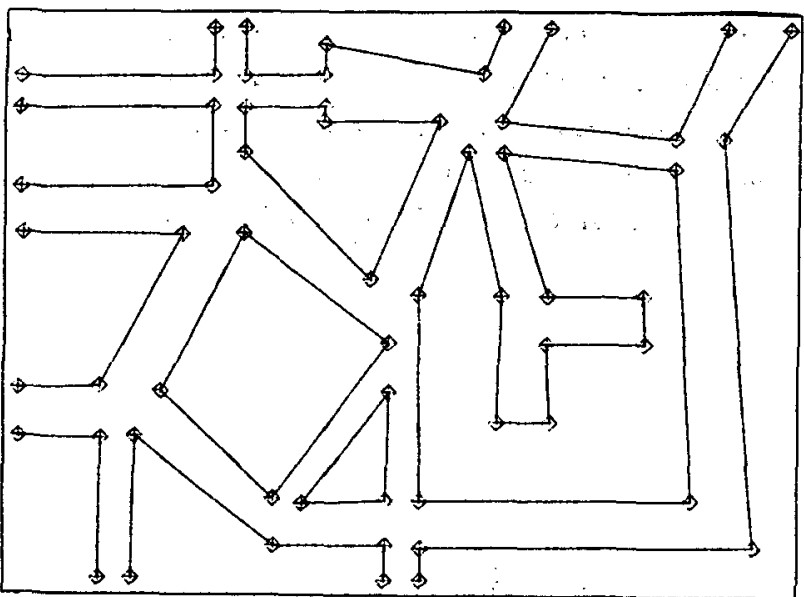

図 1. 道路粶・点テストデータ

をもとに説明する。

\section{1 三角形分割}

互いに離ればなれの幾何的デー夕単位に対し、そ れら相互の位置関係により定義される対象を判定あ るいは生成するのには、平面をそれらの単位に即し て位相的に円盤と同相な多角形に分割するのが通常 である。この研究では三角形分割を使っている。即 ち、道路縁を表わす座標点列の各点（以下縁点と呼 ぶ）を頂点とする三角形分割を始めに生成する。そ の際閉じたボリラインについては重複を避けるため に終わりの点を除いておく。三角形分割法には何種 類かあるがここではVoronoi分割の双対である Delaunay の三角形分割を用いた。分割結果を 図 2 に示す。

\section{2 デー夕構造}

使用したデー夕構造（演算操作のためのメモリー 上でのそれ）は以下のようなものである。

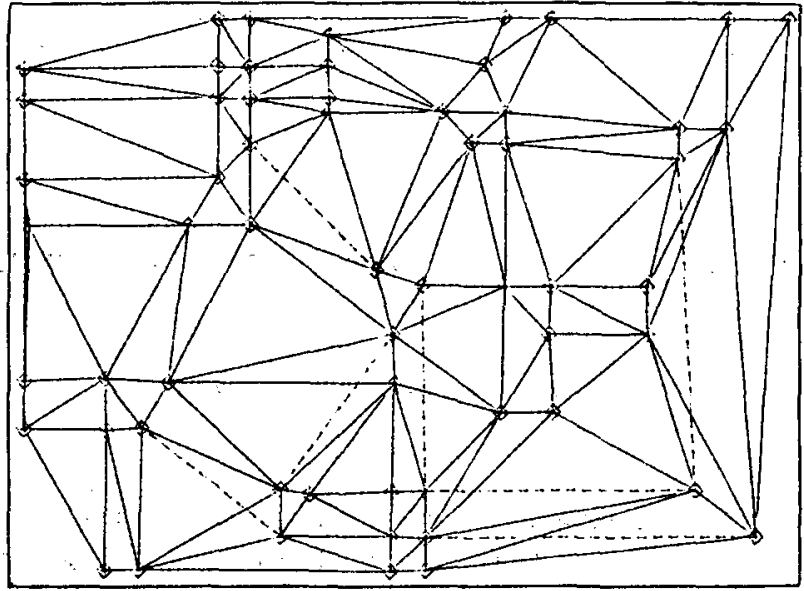

図 2. 縁点の Delaunay 三角形分割

(1) 粶点：粶点相互は FROM と TO とからなる双方 向リストでつなぎ、もとの道路縁情報を保持する。 閒じたポリラインの場合は循環リストとなり、それ 以外は両端で途切れるリストとなる。

（2）三角形：Voronoi 分割の頂点に相当する。 Voronoi 分割の方法によっては三角形とならない場 合があるが、使用したアルゴリズムが文献[1]によ るものなので必ず三角形となる。なお外部領域も一 つの三角形として（実際の頂点数は 3 より多いが） 登録する。以下の操作で三角形の併合等で区分域が 三角形でなくなることが起こり得るが、誤解を生じ るおそれのないかぎり三角形とよぶことにする。あ えて三角形とは限らないことを強調する際には多角 形とよふ。

(3) 辺：三角形分割の辺である。縁点並びに三角形 に発線、着線、左迴り線、右廻り線のポインタを用 意し、それぞれについてリスト表現する。

な抆、データを読み込む時にはそれぞれの要素の 識別子と格納場所のアドレスを対応させるためにイ ンデクス・ツリーの平衡管理に AVL 木による探索 構造を使っているが、読み込み後はすべてアドレス で操作出来るためそのための記憶領域は解放してい る。

\section{3 縁辺の挿入}

図 2 に破線で示したように、縁点に対する三角形 分割の結果、道路縁が三角形の辺にならないことが 
起こり得る。道路緣をなす縁点間の区間を以下縁辺 と呼ぶ。三角形の辺になっていない縁辺を追加して 三角形分割を再編する処理を行う。手順を以下に示 す。

\section{各縁点について |}

TO リストの先の縁点(もしあれば)との間が 辺として登録されているかどうかを調べる;

\section{もし登録されていなければ |}

先の縁点への方向が含まれる三角形とそ の交差する辺を求める;

その辺の反対側の三角形を手前と併合し 辺を削除する;

先の縁点に行き着くまで|

先の三角形の残る 2 辺の内どちらと交

差するか判定する;

併合、削除処理をする;

縁点間に辺を挿入し、併合で出来た多角 形を二つに分割する;

二つの多角形について 1

三角形分割をおこなう;

$$
\text { । }
$$

\}

\section{1}

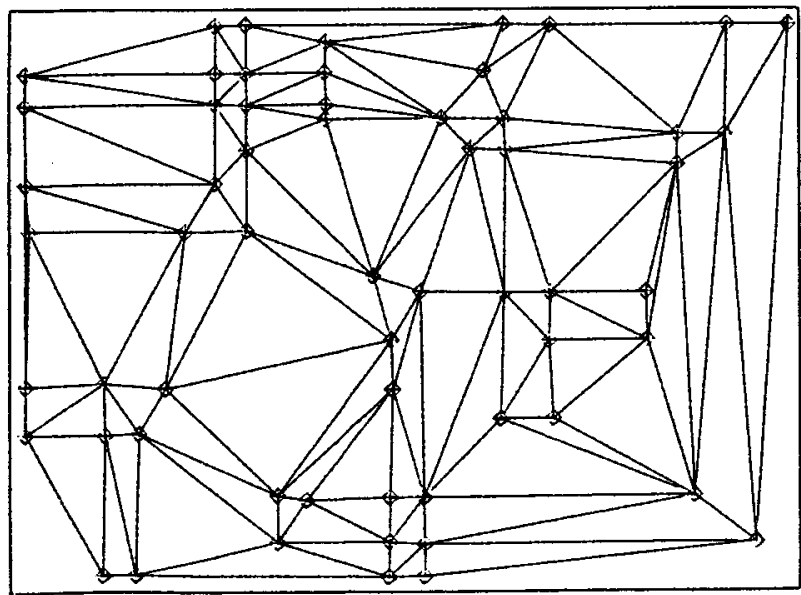

図 3. 縁辺挿入 ·再編後の三角形分割

この処理を行った結果を図 3 に示す。 なお縁辺を挿入した結果出来る二つの多角形の内 左側のものは非道路であるからここで除外できるよ
うに見えるが、他の未登録縁辺について更に处理対 象となる可能性があるため、双方とも三角形分割処 理を施す。ここでの三角形分割は多角形に対するそ れであるが、挿入辺に対し両端部を除く多角形のポ リラインが単調であることを利用できる。

2.4 道路外三角形の削除

この段階で三角形は道路内のものと道路外のもの とからなり、後者を削除する処理を行う。手順は下 記の通りである。

各縁辺を有する三角形について

もし FROM/TOリストの方向に対し左側であれば 削除する（実際には外部領域に併合する）； \}

各三辺とも縁辺でない三角形について $\mid$

もし筷接領域がすべて外部領域ならば削除する （外部領域に併合する）；

1

各三辺とも縁辺でない三角形について 1

二辺についての冽接領域が外部領域ならば削除す る（外部領域に併合する）；

外部領域以外の䇟接三角形についてこの処理を遡 行する；

\}

\section{各辺について}

両側が外部領域ならば削除する；

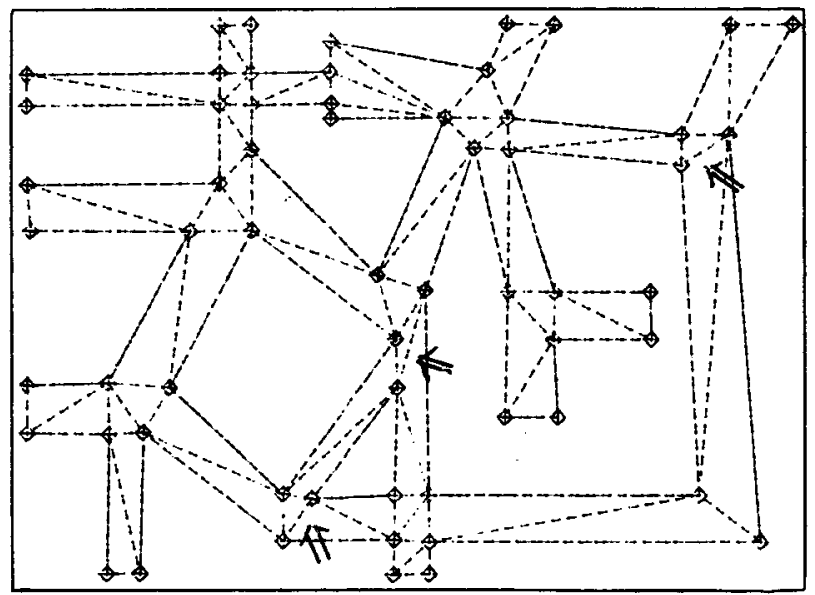

図 4. 非道路部三角形を削除した結果 
なお辺の削除処理で稼辺が削除されることも起こ り得る。それについては後述する。

処理結果を図 4 に示す。

\section{5 ノド三角形の整形}

ここまでの処理で三角形は辺のうち幾つが縁辺に なっているかで 0,1,2,3 のいづれかに分類される。 0の三角形はそこで道路区間が出会うので以下ノー ド三角形とよふ。1の三角形は道路区間に相当する ので区間三角形とよふ。2の三角形は行き止まりを 表わすので行き止まり三角形とょぶ。3の三角形は 系統性の無い非連結道路片であるが実際上は無視で きる。なおそれ以外に外部領域に瞵接する三角形が あり、図郭内だけでみれば行き止まりであるが、隣 接図郭との併合時にはつながる可能性があるので境 界三角形として区別する。

実際の三叉路にあっては 図 4 の矢印で示すよう に当該三角形が瘦せてしまう場合があり、ネット ワークの形状を歪める要因になる。このためノード 三角形については以下の手順で整形を加える。

各ノード三角点について |

最短辺とこれに対する頂点を求める；

頂点からの一つないし二つの縁辺について

最短辺の垂直二等分線との交点をもとめそれ が縁辺上にありかつ最短辺の二等分点との距 離がもとの頂点との距離未满であったら 交点に頂点を移し、隣接三角形に対し必要 な処理を加える； \}

\}

整形結果を図 5 に示す。

\section{6 三角形の併合}

この段階ではすべて交差点は三叉路として表現さ れている。実際には十字路等とみなされるもので あっても三角形分割の成りゆきで三叉路に分解され

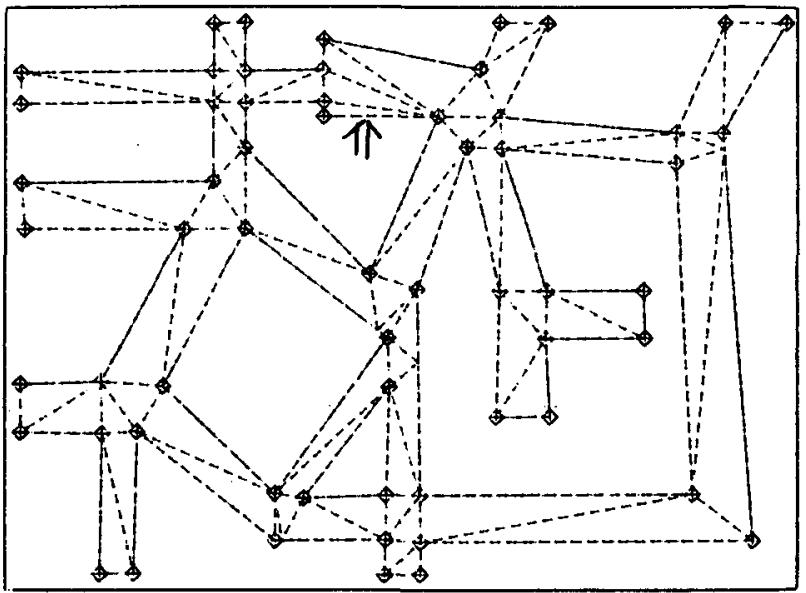

図 5.ノード三角形の整形結果

てしまうのである。このためノード三角形が隣接し ている場合はこれを併合する。

これ以外に行き止まり三角形の問題がある。実際 に行き止まりとみなしてよい場合以外に、幅員の変 化する䇢所やカーブ箇所で道路縁がくはむと図 5 の 矢印で示すように行き止まり三角形が発生してしま う。そこで行き止まり三角形とノード三角形あるい は多角形が隣接する場合はこれを併合する。この場 合併合相手がノード三角形であると新たに出来る多 角形は区間多角形となる。ノード多角形が併合相手 であるとノード多角形であっても縁辺を有するもの が生じることになる。処理結果を図 6 に示す。

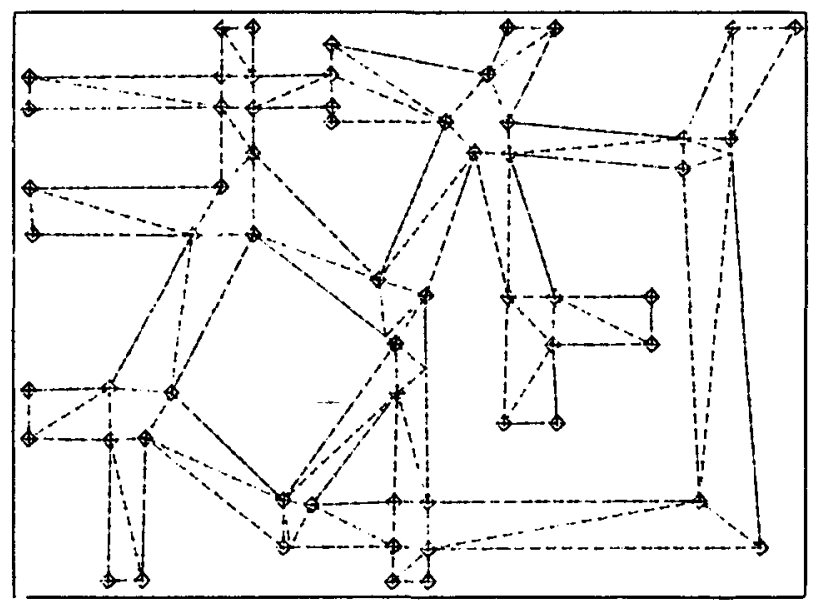

図 6. 三角形の併合の䊅果

2.7 ネットワーク・データの出力

ここまでの処理で（2.5,2.6は不要ならば省略する 
ことも出来る) ネットワークは三角形 (多角形) の

瞵接関係として表現されている。それを通常のネッ トワーク処理にそのまま使える形式で出力するため に以下の手順を用いた。

各ノード三角形（多角形）については

識別番号を付番し、困心座標を求めてノード. ファイルに出力；

識別番号と境界座標列をノード形状ファイルに 出力;

1

\section{各境界三角形について}

識別番号を付番し、外部領域に接する辺の中点 をもとめてノード・ファイルに出力； )

各ノード三角形（多角形）について

各縁辺でない辺について

醉が末処理であれば |

リンク識別子を付番し䇟接三角形（多角形） がノード三角形か境界三角形ないし行き止ま り三角形になるまで

処理済みフラグを立てる；

左右の縁辺を左縁ファイル、右縁ファイル に出力する；

非縁辺の中心点を結ふ線を中心線ファイル に出力する；

三角形（多角形）の面積を中心線延長で除 したものを区間幅員として、最大・最小を 記録しかつ面積を累計する；

\}

\section{終端三角形が行き止まりのとき|}

ノード識別子を付番し、そこにはいる中心 線の方向が交差する辺の交点を求めノー

ド・ファイルに出力； 1

リンク識別子とその起終点のノード識別子を 位相ファイルに出力；

リンク識別子、延長累計（起終点のいずれか あるいは双方がノード三角形ならばノード内
延長を加算する）、最小幅員、最大幅員、平 均幅員（リンクに含まれる三角形（多角形） の総面皘をノード内延長を除いた延長累計で 除したもの）を属性ファイルに出力する；

出力内容は以下の通りである。

(1) ノード・ファイル：ノードの識別子、座標、 ノード区分（一般ノード、図郭境界点、行き止 まり点)

（2）位相ファイル：リンクの識別子、始点ノード識 別子、終点ノード識別子

（3）属性ファイル：リンクの識別子、延長、最小幅 員、最大幅員、平均幅員

(4) ノード形状ファイル：ノードの識別子、座標。 サイクルとして表現。行き止まり点、図郭境界 点については出力しない。

（5）中心楾ファイル：リンク識別子、座標

（6） 側線ファイル：リンク識別子、座標、左右区分 出力結果の内、中心線ファイル、ノード・ファ イル、側線ファイル内容を 図 7 に示す。

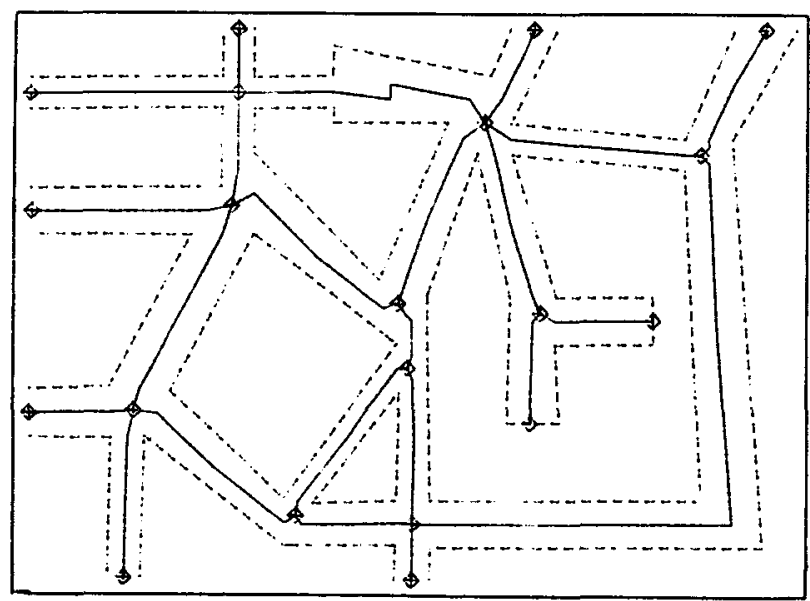

図 7. 生成したネットワーク

なお、この処理ではネットワークに非連結成分が あってそれにノード三角形 (多角形) が含まれてい ない場合、その部分は出力されない。出力が必要な らそのように改めることは容易である。

\section{3. 数值地図 10,000 での検証}


前章で紹介した処理系を国土地理院数値地図 10,000 「新宿」に適用した。平面道路のデータ全体 で、粶点数は57,627、非道路区画の総数は $3,978 て ゙$ ある。粶点の重複、椂辺の交差についてチェック を行ったが、重複・交差とも無かった。緣辺の方向 について国土地理院の作業規定では特定していない が、49の道路縁を除いては左迴りとなっていた。 方向を特定しておけばこの研究で採用した方法をそ のまま適用できる。全図幅のうち局所平面直交 座標系で $(250,1750)-(1250,2750)$ の新宿西口1平方キ 口の区画を抽出して処理した結果を示す。この区画

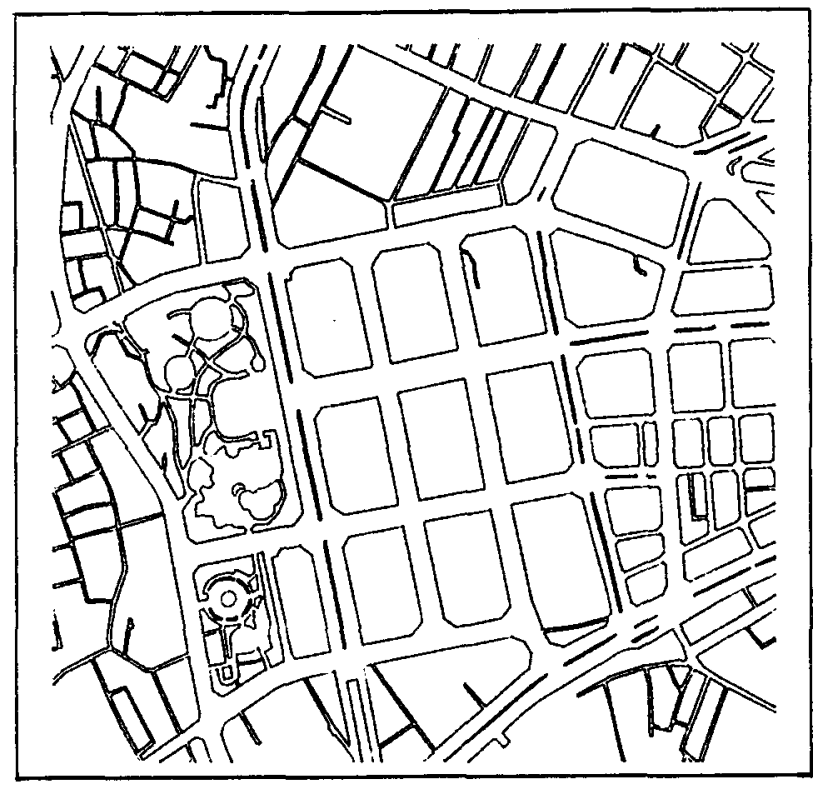

図 8. 数值地図 10,000 新宿西口

に含まれる粶点は 2,238 道路椂は 198 である。 図8は原データをそのままプロットしたものであ る。新宿西口区域で西口公園内の 園路、高層ビル 街を含み、また周辺には住宅街も含まれる。

処理結果のうち中心線ファイル、側線ファイル、 ノード・ファイルの内容を 図 9 に示す。な技の 内矢印で示した西口高層ビル街の右側でネットワー クが途切れているが、この部分で中央分離帯縁の 方向が逆転していた結果でる。

\section{4. 考察}

ここで提示したネットワーク生成アルゴリズムは
十分実用に耐えるものであると考える。最初の三角 形分割以降は各段階の処理に数值や位相に関する不 安定要因は特になく、頑健な方法である。計算効率 については、三角形分割結果の読み込みの後、処理 は三角形、辺あるいは縁点の巡行の繰り返しで行わ れ、一件あたりの処理コストはデータの全体の大き さ $\mathrm{N}$ に依存しない。即ち全体の時間コストは $\mathrm{N} に$ 比例するオーダーで収まる。三角形分割の読み込み 時には各要素識別子と格納箇所の番地を対応づける のにAVL 木を使ていることから $N^{*} \log (\mathrm{N})$ のオー ダーの時間を要している。この点は識別子から番地 への直接変換を行うことでNに比例する程度に効率 を向上することは可能である。 な抢残るいくつ かの問題点を列挙しておく。

(1) データの幾何学的整合性について

この研究で採用したアルゴリズムが妥当するのは 道路縁データが間断なくかつ一定の方向でとられて いるという前提のもとである。数值地図 10,000 の作 成にあたってそのようなデータ要件を定めた「ディ ジタル・マッピング標準仕様」を採用したことはそ の意味でも大変有意義なことであったと考えられ る。ところが残念なことに道路縁の方向という最も 基幹的位相要件に関してはデータ仕様に採用されな かった。この種のデータ整備に於てはいくつかの幾 何学的条件、特に位相的条件を満たしておくことが その利用価値を大いに高めるのであり、また処理系 とデータとの一体化という計算機工学的要請にもか なうのである。たたしこの研究で使った三角形分割 で内部三角形と外部三角形とが縁辺でない辺で䇟接 するのは矛盾であるという性質を使って方向を修正 することは可能である。

(2) 図郭をまたがるネットワークについて

地理情報のデータ単位は図垶毎にファイル化され るのが通例である。その場合、図郭をまたがっての 処理を保障する必要が生じる。数值地図 10,000 では 座標系が図郭每の平面直角座標系となっており、一 方図郭の境界は経緯度で決められているため図郭境 界上の点を矩形の垂直・水平線に正確に乗った点と 


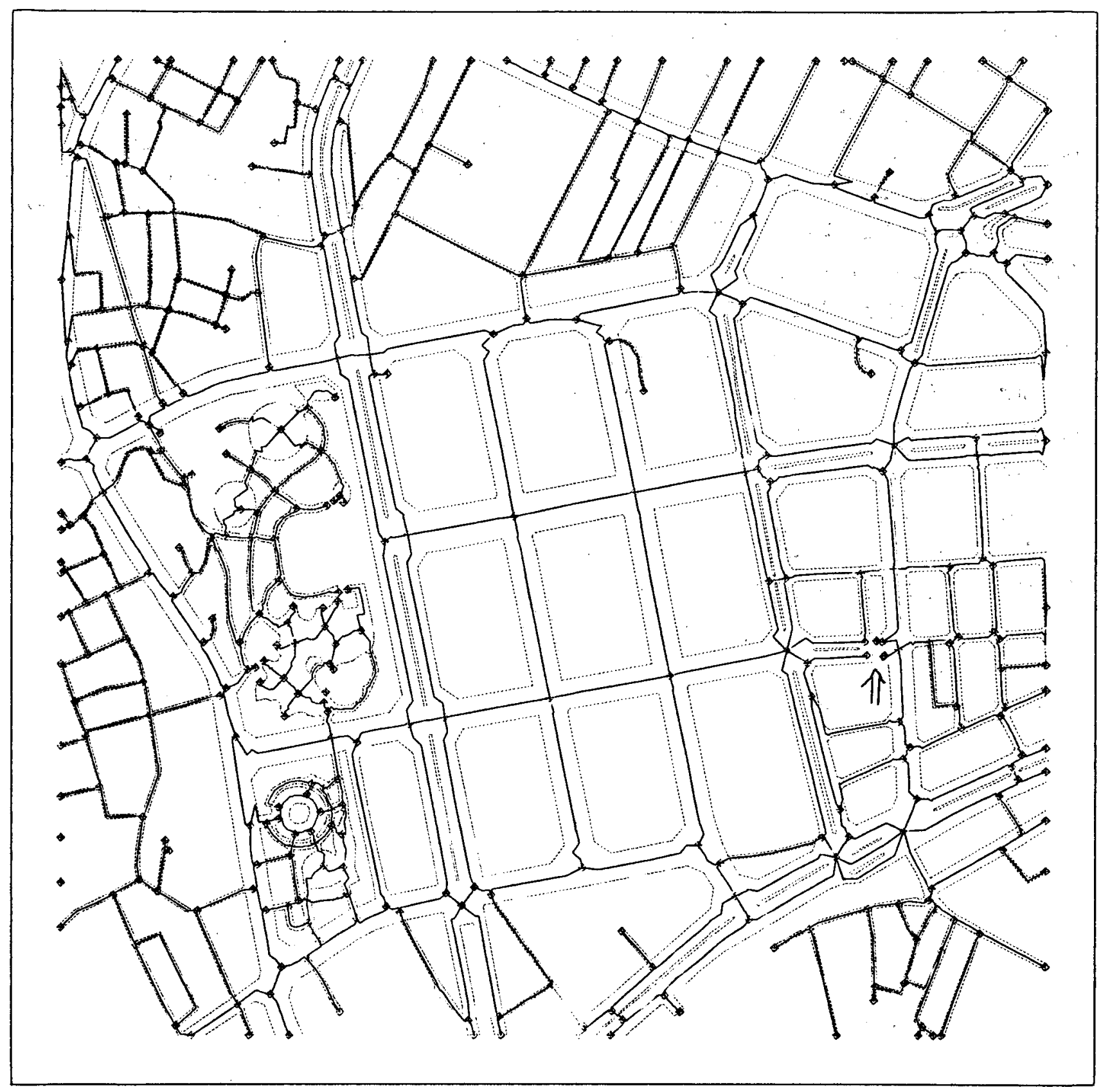

図 9. 生成された道路ネットワーク

\section{して識別することは出来ない。}

この研究で提示した方法では、図垶境界のノード が識別されるので図郭の併合は容易であるが、三角 形分割の結果出来る凸包の境界に合致する縁辺は削 除されてしまい、隣接図郭でも同様なことが起こる ためその部分の道路が久落してしまうという問題を 残している。削除縁辺は識別可能であるからそれを 生成ネットワークと結びつけて出力しておくなどの 処理を考える必要がある。
（3）リンク中心線、ノード代表点の定め方

図 9 にみるようにこの方法で取り出した道路中心 線は三角形分割に規定されて一部ジグザグな形とな ることがある。視覚的に不自然というだけでなく延 長や幅員の值にも影響を与える。中心線は三角形分 割によらず両側線から別途判定した方がよい結果が 得られるであるう。

ノード代表点は図心をあてているが、系統だった 路線がノード部で屈曲するなどの傾向がみられる。 
なお隅切りのある交差点などでは実際には単一の交 差点とみなされるものがノード三角形と区間三角形 の混合になる可能性があり、改善の余地はある。

(4)三角形分割法について

ここでは Delaunay の三角形分割を使っている が、三角形分割の方法により最終結果のネットワー ク形状にどの様な差異が生じるかについては未検討 である。またここでは縁点による三角形分割の後で 縁辺の挿入・再編を行っているが、始めから縁辺を 辺に加えた三角形分割も考えられるし、その場合非 道路部三角形を発生させないで処理の効率化、メモ リーへの負荷の軽減を図ることも可能であろう。

(5) 立体交差

入カデータの条件から生成されるネットワークが 立体交差を表現していないことは当然である。この 点はデー夕標準の欠点とみるべきではなく、二次的 加工に委ねるのが妥当と考えられる。区画街路と自 動車専用道路等との結節についても同様である。

なおこの方法の応用としてラスター/ベクター変 換に扔ける芯線化処理が考えられる。道路粶からの ネットワーク生成と芯線化とは本質的に同じ性格を もった課題である。芯線化は等高線のように本来交 差のない、あるいは例外的な対象の処理に向くが、 交差部の処理に難があるとされてきた。交差箇所に 局部的にここでの方法を適用することでその弱点を 補えるのではないかと考えている。

末筆ではあるが、道路縁を表わす座標点の三角形 分割という発想が浮かんたのは参考文献の組合せ構 造を優先させることでヴォロノイ図を安定的に生成 させるアルゴリズムのおかげである。いろいろご指 導いただいた伊理先生、杉原先生に厚く御礼申し上 げる。

なお本研究でのプログラム開発、テストはCompact Micro VAX II 上で VAX FORTRAN, VAX Cを 使って行った。たまたまこの環境でのまとまったブ ログラム開発はこれが最後となり、永年酷使した同 機にいささかの哀別の念を表するのをお許し願いた
W。

\section{参考文献}

Sugihara, K., Iri, M., (1992) Construction of the Voronoi Diagram for One Million Generators in Single-Precision Arithmetic, Proceedings of the IEEE, 80: 9, 1471-1484. 